\title{
Joanna Kizielewicz
}

Akademia Morska w Gdyni

e-mail: j.kizielewicz@wpit.am.gdynia.pl

\section{KSZTALTOWANIE CEN OFERT TURYSTYCZNYCH NA RYNKU USEUG MORSKIEJ ŻEGLUGI WYCIECZKOWEJ}

\section{PRICING POLICY OF TOURIST PACKAGES ON THE CRUISE SHIP TOURISM MARKET}

DOI: $10.15611 / \mathrm{pn} .2017 .473 .28$

JEL Classification: M21

Streszczenie: Na rynku usług morskiej żeglugi wycieczkowej obserwowany jest trend do obniżania cen uczestnictwa w rejsach, czego powodem jest silna konkurencja pomiędzy koncernami morskich linii wycieczkowych. Aby podtrzymać zainteresowanie wśród konsumentów na rynku turystycznym, sięgają one po różne rozwiązania w kształtowaniu polityki cenowej, aby ich oferty wciąż były konkurencyjne na rynku. Celem artykułu jest identyfikacja metod kształtowania cen ofert turystycznych przez organizatorów rejsów morskich, w tym koncerny morskich linii wycieczkowych, oraz stosowanej przez nich polityki cenowej. W artykule zaprezentowano wyniki badań przeprowadzonych metodą eksploracyjną przy wykorzystaniu dostępnych na rynku ofert rejsów wycieczkowych proponowanych przez wiodące koncerny żeglugi wycieczkowej oraz publikowanych przez nich rocznych sprawozdań finansowych i raportów marketingowych.

Słowa kluczowe: żegluga wycieczkowa, polityka cenowa, oferty turystyczne.

Summary: There is a trend to decrease prices of cruise ship offers on the cruise ship tourism market due to the strong competition among cruise lines corporations. To sustain interest among consumers on the tourist market these entities look for various solutions in the development of the pricing policy to make their deals competitive. The purpose of this article is to identify the pricing methods of tourist offers by the organizers of cruise voyages including cruise lines corporations and their pricing policy. The article presents the results of the tests carried out by applying the exploratory method by using the cruise offerings available on the market suggested by the leading cruise lines corporations and published in their annual financial statements and reports.

Keywords: cruise ship tourism, pricing policy, tourist packages. 


\section{Wstęp}

Proces kształtowania cen produktów w przedsiębiorstwach jest złożony i uzależniony od wpływu wielu czynników wewnętrznych i zewnętrznych. Każde przedsiębiorstwo samodzielnie opracowuje własną politykę cenową, a na jej podstawie ustala ceny podstawowe i strategie cenowe. Wszystkie te działania muszą być podporządkowane osiągnięciu zakładanych przez przedsiębiorstwo celów strategicznych, w tym celów finansowych oraz marketingowych i społecznych.

Cena to „wartość towaru lub usługi wyrażona w jednostkach pieniężnych” [Panasiuk (red.) 2005]. Natomiast polityka cenowa to, za J. Mikołajczykiem [2008], „zbiór decyzji sprzedawcy zmierzających do skoordynowania procesu kształtowania cen produktów z ogółem działań dotyczących dostarczania wartości (korzyści) nabywcom z danego rynku docelowego". K. Appelt [2015] podkreśla także, że kształtowanie się cen jest procesem popytowo-podażowym, uzależnionym od sądów wartościujących konsumentów. Z kolei strategia cenowa przedsiębiorstwa określana jest jako wybór optymalnego poziomu i struktury cen sprzedawanych towarów w długim okresie [Dyhdalewicz 2011].

$\mathrm{Z}$ raportu Cruise Line International Association [CLIA 2014] wynika, że cena stanowi najważniejszy motywator przy podejmowaniu decyzji przez konsumentów o nabyciu morskich rejsów wycieczkowych. Tezę tę potwierdza również R. Seweryn, która zauważa, że to właśnie cena produktu stanowi główne kryterium jego wyboru przez konsumentów na rynku usług turystycznych, i to zarówno w odniesieniu do mniej zamożnych, jak i dobrze sytuowanych. Przy czym w pierwszej grupie cena ma kluczowe znaczenie dla podjęcia decyzji nabywczych, a w odniesieniu do drugiej - znaczenie symboliczne [Seweryn 2005], gdyż pojawia się tutaj efekt Veblena (efekt snobizmu), który mówi, że popyt na dobro wzrasta wraz ze wzrostem jego ceny [Bartkowiak 2008].

\section{Cel i metodyka badań}

W artykule zaprezentowano wyniki badań przeprowadzonych metodą eksploracyjną przy wykorzystaniu dostępnych na rynku ofert rejsów wycieczkowych proponowanych przez wiodące koncerny żeglugi wycieczkowej oraz publikowanych przez nich rocznych sprawozdań finansowych i raportów marketingowych. Celem artykułu jest identyfikacja metod kształtowania cen ofert turystycznych przez organizatorów rejsów morskich, w tym koncerny morskich linii wycieczkowych, oraz stosowanej przez nich polityki cenowej. W pracy postawiono następujące pytania badawcze:

1) Jakie strategie cenowe stosowane są przez koncerny morskich linii wycieczkowych?

2) Jakie czynniki mają wpływ na politykę cenową na rynku usług morskiej żeglugi wycieczkowej? 
3) Jak wygląda proces kształtowania cen ofert morskich rejsów wycieczkowych?

Do celów badawczych postawiono hipotezę $H_{o}$, że wysokie koszty eksploatacyjne statków wycieczkowych oraz koszty operacyjne na lądzie ponoszone przez koncerny morskich linii wycieczkowych powodują, iż ich polityka cenowa jest zorientowana na minimalizację kosztów jednostkowych (strategia kosztowa).

Oferta morskich przewoźników wycieczkowych na rynku jest bardzo bogata i trudno jest dokonać wyczerpującej analizy w odniesieniu do wszystkich podmiotów i oferowanych przez nich produktów. Stąd też w niniejszym artykule analizę ograniczono do trzech wiodących koncernów morskich linii wycieczkowych na świecie oraz proponowanych przez nie ofert tzw. standardowych, które cieszą się największym zainteresowaniem wśród klientów: 1) rejsy trwające od 3 do 14 dni; 2) rejsy kombinowane, tj. z zawijaniem do portów przystankowych; 3) zakres usług wliczonych w cenę podstawową rejsu, tj. pobyt na statku, zakwaterowanie w kabinie, wyżywienie na statku i usługi świadczone na statku. Wyodrębnienie tych zmiennych umożliwiło dokonanie analizy porównawczej.

\section{Polityka cenowa i strategie cenowe stosowane w przedsiębiorstwach}

Każde przedsiębiorstwo dąży do maksymalizacji zysków poprzez wzrost sprzedaży oraz utrzymanie pozycji na rynku. Przedsiębiorcy stawiają sobie również inne cele biznesowe związane ze stosowaną strategią cenową: zwiększenie udziału w rynku, poprawę własnego wizerunku rynkowego czy wyróżnianie własnej oferty w stosunku do oferty konkurentów itp. [Pietras 2001]. Ważnym elementem tego procesu jest stosowana polityka cenowa w przedsiębiorstwie oraz strategie ustalania wysokości cen produktów oferowanych do sprzedaży. Aby osiągnąć zakładane cele, przedsiębiorcy stosują w praktyce różne strategie, np. strategie niskich cen (penetracji rynku) [Panasiuk (red.) 2011], strategie średnich cen, strategie wysokich cen (tzw. skimming) [Sławińska 2002], a także strategie cen prewencyjnych (grabież cenowa) [Pietras 2001, Trojanowska 2012] i inne (tab. 1).

Przedsiębiorcy muszą podejmować decyzje, do którego segmentu rynku kierują swoje towary i usługi. Ustalając ceny, wybierają np. strategię popytową (orientacja popytowa), której założeniem są reakcje na zachowania się konsumentów na rynku. Zgodnie z prawem popytu wzrost cen dóbr konsumpcyjnych i usług powoduje spadek popytu turystycznego, spadek cen pobudza popyt turystyczny [Panasiuk (red.) 2011], ale oczywiście są również przedsiębiorstwa, które decydują się na wybór strategii preferencji jakościowych i luksusu rynkowego (premium strategy), kierowanej do konsumentów tzw. markowych, którzy cenią sobie dobrą jakość za wysoką cenę [Pietras 2001]. Ch. Cooper i in. [1998] podkreślają, że właśnie relacja ceny do jakości oferowanych produktów na rynku turystycznym ma istotny wpływ na decyzje nabywcze konsumentów. 
Tabela 1. Rodzaje strategii cenowych stosowanych w przedsiębiorstwach

\begin{tabular}{|c|c|}
\hline Nazwa strategii cenowej & Opis cech charakterystycznych \\
\hline Strategia popytowa & $\begin{array}{l}\text { Stosowanie cen produktów kształtowanych przez warunki rynkowe } \\
\text { i popyt konsumencki. }\end{array}$ \\
\hline Strategia kosztowa & $\begin{array}{l}\text { Stosowanie cen w oparciu o analizę nakładów poniesionych na } \\
\text { wytworzenie towarów i usług. }\end{array}$ \\
\hline Strategia konkurencyjna & $\begin{array}{l}\text { Stosowanie cen w oparciu o analizę cen podobnych towarów i usług } \\
\text { oferowanych przez konkurentów na rynku. }\end{array}$ \\
\hline Strategia szybkich zysków & $\begin{array}{l}\text { Stosowanie wysokich cen dla nowo wprowadzanych towarów i usług } \\
\text { na rynek przy dużych nakładach na promocję. }\end{array}$ \\
\hline $\begin{array}{l}\text { Strategia prewencyjnego } \\
\text { stosowania cen (dumping) }\end{array}$ & $\begin{array}{l}\text { Stosowanie cen poniżej kosztów wytworzenia w celu zdobycia } \\
\text { masowego rynku } \\
\text { i utrudniania wejścia na rynek konkurencji. }\end{array}$ \\
\hline $\begin{array}{l}\text { Strategia preferencji } \\
\text { jakościowych lub luksusu } \\
\text { rynkowego }\end{array}$ & $\begin{array}{l}\text { Stosowanie wysokich cen dla towarów i usług wysokiej jakości, } \\
\text { adresowanych do klientów tzw. markowych, tj. wybierających luksus. }\end{array}$ \\
\hline Strategia dobrej jakości & Stosowanie niskich cen dla towarów i usług średniej jakości. \\
\hline $\begin{array}{l}\text { Strategia oszczędności (tanich } \\
\text { dóbr) }\end{array}$ & $\begin{array}{l}\text { Stosowanie redukcji jednostkowych kosztów wytwarzania } \\
\text { i marketingu w celu zwiększenia obrotów. }\end{array}$ \\
\hline Strategia stabilizacji cen & $\begin{array}{l}\text { Stosowanie w miarę stabilnych cen towarów i usług w dłuższym } \\
\text { okresie. }\end{array}$ \\
\hline $\begin{array}{l}\text { Strategia wysokich cen } \\
\text { (skimming) }\end{array}$ & $\begin{array}{l}\text { Stosowanie najwyższego możliwego poziomu cen w krótkim okresie } \\
\text { w celu maksymalizacji zysków. }\end{array}$ \\
\hline $\begin{array}{l}\text { Strategia niskich cen } \\
\text { (penetracji rynku) }\end{array}$ & $\begin{array}{l}\text { Stosowanie cen na niskim poziomie w celu zwiększenia udziału } \\
\text { w rynku. }\end{array}$ \\
\hline $\begin{array}{l}\text { Strategia rabunkowa } \\
\text { (rabunkowa) }\end{array}$ & Stosowanie wysokich cen dla towarów i usług o niskiej jakości. \\
\hline
\end{tabular}

Źródło: opracowanie własne na podstawie [Pietras 2001; Hann, Dodge 1997; Panasiuk (red.) 2007, 2011].

Z kolei inni przedsiębiorcy, dokonując wyboru strategii cenowej, bacznie przyglądają się konkurencji i stosują takie rozwiązania, które są reakcją na zachowania rynkowe konkurentów (orientacja konkurencyjna). Natomiast wciąż najbardziej popularną strategią cenową adaptowaną przez przedsiębiorców jest strategia kosztowa, polegająca na obliczaniu kosztów wytworzenia, dystrybucji i sprzedaży produktu (orientacja kosztowa) [Pietras 2001, Kaczmarek i in. 2005]. Dość często stosowana jest też strategia porównań międzynarodowych, polegająca na dostosowaniu cen produktów do poziomu cen oferowanych w innych krajach, oraz strategia porównań wartości substytutów, czyli ustalaniu cen w oparciu o analizę porównywalnych dóbr i usług o podobnej jakości [Panasiuk (red.) 2007]. W praktyce stosowane są również strategie mieszane, np. konkurencyjno-popytowa czy kosztowo-popytowa [Panasiuk (red.) 2011]. 
Niestety, wielu badaczy w literaturze zagranicznej podkreśla, że wciąż większość podmiotów gospodarczych poświęca zbyt mało uwagi i środków na wypracowanie efektywnej polityki cenowej, budowanie modeli, procesów i strategii ustalania cen w przedsiębiorstwach [Bengstson 2014, Olve i in. 2013], co z pewnością nie sprzyja osiąganiu sukcesu rynkowego.

\section{Czynniki oddziałujące na formułowanie polityki cenowej i strategii cenowej przez koncerny morskich linii wycieczkowych}

W literaturze ekonomicznej spotykane są różne kryteria różnicowania cen towarów i usług. J. Kaczmarek i inni podają, że ceny produktów turystycznych można różnicować ze względu na kryterium: czasu, grupy odbiorców, wielkości transakcji, terminu sprzedaży, formy zapłaty czy miejsca w systemie dystrybucji produktów turystycznych [Kachniewska i in. 2012, Kaczmarek i in. 2005]. Wybór przez przedsiębiorców modelu strategii cenowej zależy od wielu czynników. Wśród najważniejszych należy wymienić: pozycję przedsiębiorstwa na rynku, zakładane cele biznesowe (wizja przedsiębiorstwa), jego zasięg oddziaływania, uwarunkowania makroekonomiczne, wyniki sprzedaży z poprzednich okresów, opinie i satysfakcja konsumentów z nabytych wcześniej produktów, ale również kulturę organizacyjną przedsiębiorstwa. A. Dyhdalewicz [2011] wskazuje również, że celem polityki cenowej w przedsiębiorstwach jest stabilizacja pozycji na rynku, utrzymanie przywództwa cenowego, a także skłonienie słabych firm do wyjścia z rynku, selekcja dostawców czy wywieranie wpływu na konkurentów. R. Bengstson [2014] wymienia jeszcze inne czynniki, jakie mogą mieć znaczenie dla koncernów morskich linii wycieczkowych w procesie kształtowania poziomu cen morskich rejsów wycieczkowych: 1) zakładane długoterminowe zyski, 2) wzrost lojalności agentów turystycznych, 3) utrzymanie reputacji na rynku, 4) podtrzymanie zainteresowania ofertą wśród potencjalnych konsumentów.

Odnosząc się natomiast do kwestii kształtowania cen morskich rejsów wycieczkowych przez koncerny morskich linii wycieczkowych, wśród najważniejszych czynników determinujących ten proces należy wymienić:

- zakres usług wliczonych w cenę morskiego rejsu wycieczkowego (oferty np. Flight\&Cruise, tj. przelot i rejs, lub Round Cruise, tj. podróż okrężna bez zwiedzania portów przystankowych);

- czas trwania morskiego rejsu wycieczkowego (3 dni, 14 dni czy rejs dookoła świata trwajacy 222 dni i in.);

- jakość oferowanych usług na statku wycieczkowym (w tym celu stosowany jest wskaźnik liczby załogi przypadającej na jednego pasażera);

- standard kabiny na statku wykupionej na czas trwania morskiego rejsu wycieczkowego (Standard, Premium, First, De Lux); 
- termin dokonania rezerwacji przed rozpoczęciem morskiego rejsu wycieczkowego (rabaty w ofercie first minute oraz last minute);

- sposób dokonania rezerwacji morskiego rejsu wycieczkowego przez konsumenta (np. u armatora linii wycieczkowych, przez Internet, za pośrednictwem agenta);

- system lojalnościowy stosowany przez koncerny morskich linii wycieczkowych dla stałych klientów;

- atrakcyjność turystyczną morskiego rejsu wycieczkowego (np. rejsy do dziewiczych obszarów czy rejsy dookoła świata);

- cechy indywidualne podróżnych (rabaty dla dzieci, rodzin, emerytów, rencistów, osób niepełnosprawnych);

- politykę rabatową uzależnioną od liczby uczestników, formy płatności, sezonu, w którym odbywa się rejs, czy innych akcji promocyjnych.

Trzeba podkreślić, że sprzedaż morskich rejsów wycieczkowych stanowi dla koncernów morskich linii wycieczkowych główne źródło przychodów. Generowane w ten sposób środki są przeznaczane na koszty eksploatacyjne statków wycieczkowych, do których należy zaliczyć koszty operacyjne (w tym: załogowe, środki sanitarno-higieniczne, zaopatrzenie sklepów na statkach, gabinetów kosmetycznych i koszty wyżywienia pasażerów) oraz koszty utrzymania statków wycieczkowych, koszty podróży statków (paliwo, opłaty portowe, opłaty za holowanie, pilotaż itd.), a także koszty kapitałowe (opłaty leasingowe, odsetki od kredytów itd.). Drugą grupę kosztów koncernów morskich linii wycieczkowych stanowią koszty ich działalności prowadzonej na lądzie, tzn. koszty utrzymania terminali pasażerskich i innej infrastruktury, wynagrodzeń pracowników administracji, oprogramowania komputerowego i systemów rezerwacyjnych, utrzymania sieci sprzedaży i dystrybucji, koszty działań marketingowych, a także organizacji wycieczek na lądzie, tzw. shorex, i przelotów czarterowych [Kizielewicz, Urbanyi-Popiołek 2015]. Stąd też wynika, że podstawą do wyliczenia przez koncerny morskich linii wycieczkowych ceny jednostkowej (na jednego pasażera) morskiego rejsu wycieczkowego powinny być ponoszone przez nich koszty całkowite, tzn. wszystkie ww. koszty eksploatacyjne i ponoszone na lądzie (strategia kosztowa). Niemniej, jak pokazują badania, koncerny żeglugowe decydują się na stosowanie różnych startegii cenowych, aby podążać za trendami i utrzymywać pozycję na rynku.

\section{Polityka cenowa i strategie cenowe wiodących koncernów morskich linii wycieczkowych na świecie}

Carnival Corporation \& PLC (CCL) to wiodący na świecie koncern morskich linii wycieczkowych z udziałem w rynku wynoszącym w 2015 r. 48,1\% w ogólnej liczbie przewiezionych pasażerów [Kizielewicz, Urbanyi-Popiołek 2015]. Jako cel główny polityki cenowej CCL stawia maksymalizację zysków ze sprzedaży rejsów morskich przy zachowaniu zadowolenia i satysfakcji. Cel ten realizowany jest poprzez różnorodne działania marketingowe, aby zwiększyć świadomość poten- 
cjalnych konsumentów, ale także przez dostosowywanie oferty do preferencji i oczekiwań konsumentów. Polityka cenowa CCL jest uzależniona od wielu czynników. Ceny rejsów morskich różnią się w zależności od:

- linii wycieczkowych,

- rodzaju i wielkości statku,

- kategorii kabin,

- długości rejsu

- sezonu, w którym odbywa się rejs.

Ponadto znaczący wpływ na kształtowanie się cen ma liczba miejsc na statkach dostępnych na rynku oraz zgłaszany na nie popyt (strategia popytowa). CCL wciąż dąży do wypracowania elastycznej polityki cenowej, która pozwoliłaby optymalizować procesy ustalania cen morskich rejsów wycieczkowych. Ceny rejsów na osobę z CCL kształtują się od 234 USD za rejs 3-dniowy do 1729 USD za rejs 14-dniowy [Cruise direct 2017], oczywiście przy założeniu, że cena jest uzależniona nie tylko od długości rejsu, ale również od rodzaju destynacji i kategorii kabiny na statku (tab. 2).

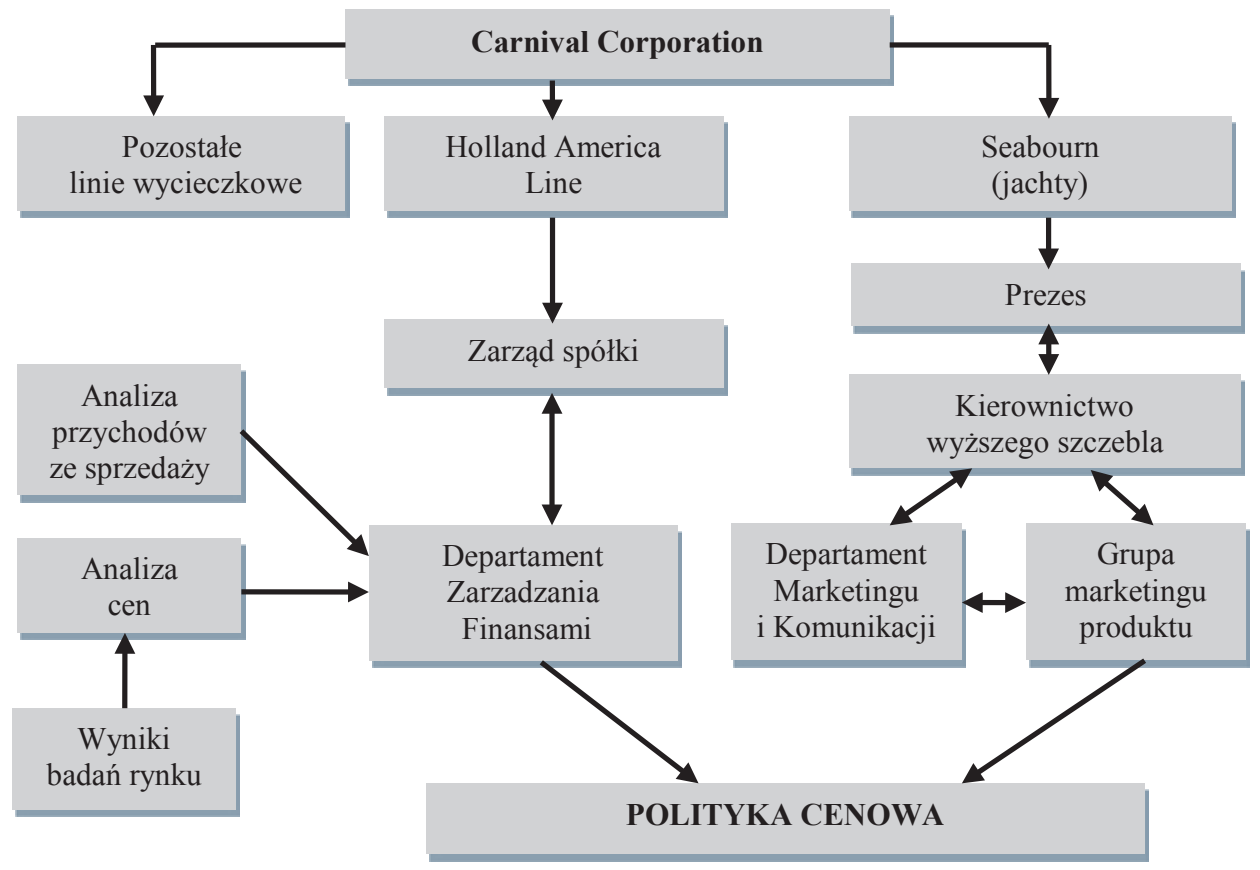

Rys. 1. Proces decyzyjny w ramach polityki cenowej w Carnival Corporation \& PLC Źródło: opracowanie na podstawie [Bengstson 2014].

Zaprezentowany na rysunku 1 przykładowy model podejmowania decyzji w ramach polityki cenowej w Carnival Corporation \& PLC pokazuje, że proces ten jest kilkuetapowy i wymaga zaangażowania podmiotów zarówno średniego, jak i wyż- 
szego szczebla [Bengstson 2014]. Dużą wagę w tym procesie przywiązuje się do analiz wyników sprzedaży oraz badań rynkowych uwzględniających zachowania konkurencji i oczekiwania konsumentów. W każdym przedsiębiorstwie model kształtowania polityki cenowej jest inny, gdyż wpływ ma na to sama struktura organizacyjna firmy, wielkość przedsiębiorstwa, tradycje oraz zakładane cele biznesowe.

Drugim ważnym graczem na rynku usług morskiej żeglugi wycieczkowej, z udziałem w przewozach pasażerskich wynoszącym 23,1\% w 2015 r. [Kizielewicz, Urbanyi-Popiołek 2015], jest Royal Caribbean Cruises Ltd. (RCCL). RCCL rozpoczyna sprzedaż swoich ofert nawet 18 albo 12 miesięcy przed rozpoczęciem podróży, proponując pierwszym klientom atrakcyjne rabaty z tytułu wcześniejszych rezerwacji. Menedżerowie RCCL bacznie śledzą wyniki sprzedaży i reagują na wszelkie zakłócenia od zakładanego planu poprzez wprowadzanie różnych akcji promocyjnych i intensyfikację działań promocyjnych na różnych rynkach. Celem polityki cenowej jest maksymalizacja zysków i zdobycie jak najszerszego rynku (strategia penetracji rynku) przy minimalizacji kosztów jednostkowych działalności (strategia kosztowa) oraz obserwacja zachowania konsumentów na rynku (strategia popytowa). Ceny rejsów morskich proponowanych przez RCCL wahają się od 666 USD na osobę do 1500 USD na osobę, przy czym odnoszą się one tzw. oferty standardowej (tab. 2).

Tabela 2. Strategie cenowe stosowane przez wiodące koncerny morskich linii wycieczkowych na świecie

\begin{tabular}{|c|c|c|c|c|}
\hline $\begin{array}{l}\text { Nazwa } \\
\text { koncernu }\end{array}$ & $\begin{array}{c}\text { Rodzaj stosowanej } \\
\text { strategii cenowej }\end{array}$ & \begin{tabular}{|c|} 
Czynniki \\
wpływające na cenę \\
podstawową
\end{tabular} & $\begin{array}{c}\text { Usługi wliczone } \\
\text { w cenę podstawową } \\
\text { za rejs }\end{array}$ & $\begin{array}{c}\text { Usługi oferowane za } \\
\text { dodatkową opłatą }\end{array}$ \\
\hline $\begin{array}{l}\text { Carnival } \\
\text { Corporation } \\
\& \text { PLC }\end{array}$ & $\begin{array}{l}\text { kosztowo- } \\
\text {-popytowa }\end{array}$ & \multirow{3}{*}{$\begin{array}{ll}\text { - } & \text { sezon w roku, } \\
\text { - } & \text { kategoria } \\
\text { kabiny, } \\
\text { - } \text { typ oferty rejsu } \\
\text { morskiego } \\
\text { - cel rejsu } \\
\text { morskiego, } \\
\text { - długość trwania } \\
\text { rejsu } \\
\text { - rodzaj linii } \\
\text { wycieczkowych } \\
\text { - rodzaj statku }\end{array}$} & \multirow{3}{*}{$\begin{array}{ll}\text { - } & \text { rejs statkiem } \\
\text { wyżywienie we } \\
\text { wskazanych } \\
\text { restauracjach } \\
\text { - udogodnienia } \\
\text { i rozrywka na } \\
\text { pokładzie statku } \\
\text { (basen, teatry, } \\
\text { kina, fitness itd.) }\end{array}$} & \multirow{3}{*}{ 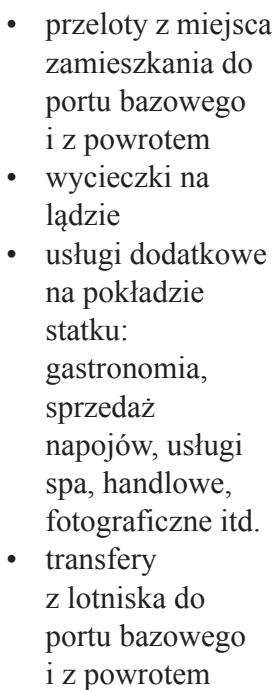 } \\
\hline $\begin{array}{l}\text { Royal } \\
\text { Caribbean } \\
\text { Cruises Ltd. }\end{array}$ & $\begin{array}{l}\text { kosztowo- } \\
\text {-popytowa } \\
\text { penetracji } \\
\text { rynku }\end{array}$ & & & \\
\hline $\begin{array}{l}\text { Norwegian } \\
\text { Cruise Line } \\
\text { Holdings Ltd. }\end{array}$ & $\begin{array}{ll}\text { - } & \text { popytowa } \\
\text { - konkurencyjna }\end{array}$ & & & \\
\hline
\end{tabular}

Źródło: opracowanie własne na podstawie [NCL 2014, RCCL 2009, CCL 2015, CCL 2015a]. 
Na podium, jeśli chodzi o udział w morskich przewozach wycieczkowych na świecie, znajduje się Norwegian Cruise Line Holdings Ltd. (NCL), którego udział w 2015 r. wyniósł 10,4\% [Kizielewicz, Urbanyi-Popiołek 2015]. NCL stosuje strategię cenową polegającą na stosowaniu atrakcyjnych cen rejsów morskich dla konsumentów dokonujących rezerwacji z długim wyprzedzeniem, również na 18 miesięcy przed rozpoczęciem podróży (strategia popytowa). Zabieg ten ma zachęcić potencjalnych klientów do podjęcia decyzji nabywczej oraz ma na celu jak najszybsze przechwycenie klientów, zanim swoje działania promocyjne rozpocznie konkurencja (strategia konkurencyjna). W zależności od zainteresowania w kolejnych etapach ceny są podnoszone lub obniżane w ramach różnych akcji promocyjnych czy systemu specjalnych kodów rabatowych. Strategia cenowa NCL jest oparta na rzetelnej analizie wyników sprzedaży, ocenie sytuacji na rynku, przewidywanym popycie oraz śledzeniu trendów. Działania tego typu powodują, że proces podejmowania decyzji odnośnie do wysokości cen jest krótszy i minimalizuje konieczność wprowadzania ofert typu last minute, aby zapełnić wszystkie miejsca na statku [NCL 2014] (tab. 2). Ceny ofert proponowanych przez NCL wahają się od 299 USD za rejs 3-dniowy do 4599 USD za 7-dniowy na osobę [Cruise direct 2017] przy założeniu, że obejmują one tylko rejs, wyżywienie oraz atrakcje na statku, ale nie obejmują przelotów do portów bazowych i przelotów powrotnych oraz wycieczek w portach zawinięć (shorex), za które podróżni muszą dokonywać opłat dodatkowych. Ceny za rejsy, tak jak u wyżej opisanych podmiotów, uzależnione są także od standardu kabiny, rodzaju statku i destynacji, sezonu i czasu dokonywania rezerwacji.

\section{Zakończenie}

Przeprowadzone badania i analizy pokazują, że przyjmowana przez koncerny morskich linii wycieczkowych na świecie polityka cenowa oraz stosowane strategie cenowe znacznie się od siebie różnią. Wynika to przede wszystkim z kilku zasadniczych czynników:

- skali działalności przedsiębiorstw na rynku usług morskiej żeglugi wycieczkowej, przez co należy rozumieć liczbę linii wycieczkowych wchodzących w skład koncernów żeglugowych oraz flotę statków, jakimi dysponują;

- zasięgu oddziaływania geograficznego koncernów morskich linii wycieczkowych;

- różnorodności ofert proponowanych na rynku przez morskie linie wycieczkowe;

- struktury organizacyjnej i kultury zarządzania w przedsiębiorstwach oferujących morskie rejsy wycieczkowe;

- formy prawnej działalności oraz struktury własnościowej armatorów morskich linii wycieczkowych, gdyż wówczas zaangażowane podmioty starają się mieć wpływ na politykę cenową i strategie cenowe stosowane przez przedsiębiorstwa, co wiąże się bezpośrednio z ich zyskami.

Analiza wykazała również, że postawiona hipoteza badawcza, która zakładała, że koncerny morskich linii wycieczkowych stosują głównie politykę cenową zorien- 
towaną na minimalizację kosztów jednostkowych (strategia kosztowa), została tylko częściowo zweryfikowana pozytywnie, gdyż wyniki badań pokazały, że wiodące na świecie koncerny żeglugowe - ze względu na silną konkurencję na rynku usług morskiej żeglugi wycieczkowej, a także rosnące oczekiwania konsumentów, którzy wciąż poszukują ofert dobrej jakości w rozsądnych cenach - realizują jednocześnie różne strategie, w tym m.in. strategię popytową i strategię konkurencyjną oraz strategię penetracji rynku.

\section{Literatura}

Appelt K., 2015, Ceny i produkcja. Pieniężna teoria cyklu koniunkturalnego w ujęciu Friedricha Augusta von Hayeka, Studia Oeconomica Posnaniensia, vol. 3, no. 2, s. 58.

Bartkowiak R., 2008, Historia myśli ekonomicznej, PWE, Warszawa, s. 138-140.

Bengstson R., 2014, Pricing methods and strategies in the cruise line industry, A case study on Carnival Corporation's premium and luxury brands, Uppsala University Campus Gotland, s. 5-39.

CCL, 2015, Carnival Corporation \& PLC, Annual Report, Miami, s. 48-49.

CCL, 2015a, Carnival Corporation \& PLC, Form 10-K for the fiscal Year ended November 2015, Washington, s. 19.

Cooper Ch., Fletcher J., Gilbert D., Wanhill S., 1998, Tourism, Principles and Practice, Second Edition, LONGMAN, New York, s. 54-55.

Cruise direct, 2017, https://book.cruisedirect.com/web/cruises/results (15.02.2017).

Dyhdalewicz A., 2011, Wybór metod ustalania cen $w$ przedsiębiorstwach handlowych, Zeszyty Naukowe Uniwersytetu Szczecińskiego, nr 625, Finanse, Rynki Finansowe, Ubezpieczenia, nr 32, Wydawnictwo Uniwersytetu Szczecińskiego, Szczecin, s. 129-131.

Hann N., Dodge M.R., 1997, Kształtowanie cen. Strategie i procedury, PWE, Warszawa, s. 126.

Kachniewska M., Nawrocka E., Niezgoda A., Pawlicz A., 2012, Rynek turystyczny, Ekonomiczne zagadnienia turystyki, Oficyna Wydawnicza Wolters Kluwer business, Warszawa, s. 91-92.

Kaczmarek J., Stasiak A., Włodarczyk B., 2005, Produkt turystyczny, PWE, Warszawa, s. 91-213.

Kizielewicz J., Urbanyi-Popiołek I., 2015, Rynek usług morskiej żeglugi wycieczkowej, PWN, Warszawa, s. 113-114.

Mikołajczyk J., 2008, Ceny i marże, [w:] Sławińska M. (red.), Kompendium wiedzy o handlu, Wydawnictwo Naukowe PWN, Warszawa, s. 142.

NCL, 2014, Norwegian Cruise Line Holdings Ltd. Form 10-K Annual Report, Edgar Online, s. 14.

Olve N.G., Cöster M., Iveroth E., Petri C.J., Westelius A., 2013, Prissättning: Affärsekologier, Affärsmodeller, Prismodeller, Lund: Studentlitteratur.

Panasiuk A. (red.), 2007, Ekonomika turystyki, Wydawnictwo Naukowe PWN, Warszawa, s. 126-131.

Panasiuk A. (red.), 2011, Ekonomika turystyki i rekreacji, Wydawnictwo Naukowe PWN, Warszawa. s. $132-244$

Pietras H., 2001, Strategie cen jako element strategii marketingowych, Annales Universitatis Mariae Curie-Skłodowska, Lublin - Polonia, vol. XXXV, Sectio H, s. 100-124.

RCCL, 2009, Marketing Plan RCCL, RCCL, Miami, s. 21.

Seweryn R., 2005, Produkt turystyczny $i$ wyznaczniki jego atrakcyjności, Zeszyty Naukowe, nr 697, Wydawnictwo AE w Krakowie, Kraków, s. 81.

Sławińska M., 2002, Zarządzanie przedsiębiorstwem handlowym, PWE, Warszawa, s. 70.

Trojanowska H., 2012, Strategia cen drapieznych. Jej efektywność i skutki dla konsumentów, Zarządzanie Zmianami, Zeszyty Naukowe, nr 1 (55), s. 15-16. 